\title{
Innate immunity mechanisms of the equine endometrium - benefit or harm?
}

\author{
Sandra Schöniger, Hilke Gräfe and Heinz-Adolf Schoon \\ Institute of Veterinary Pathology, Faculty of Veterinary Medicine, Leipzig University, Leipzig, Germany
}

\begin{abstract}
Summary: The reason for the increased susceptibility of some mares towards persistent post-breeding endometritis ("susceptible mares") is still undetermined. The equine endometrium is equipped with innate immunity mechanisms and the immunomodulatory enzyme indoleamine 2,3-dioxygenase (IDO). Endometrial epithelial cells represent the main resident cell population with afferent and efferent innate immune functions. They express Toll-like receptors (TLRs) 2, 4 and 6, the antimicrobial peptide beta-defensin and IDO. TLRs and betadefensins are involved in bacterial defences, whereas IDO restricts bacterial growth and prevents exaggerated immune responses. The orderly expression of these components is beneficial for uterine health. Their dysregulation can evoke cellular injury, reduced bacterial defence and ongoing inflammation. Thus, it appears likely that a dysfunctional expression of one or several of these factors can predispose mares to persistent endometritis. Glands with endometrosis have an aberrant beta-defensin and IDO expression, i.e. in comparison to healthy glands immunostaining for beta-defensin is increased and IDO immunolabelling is diminished. Regarding their endometrial IDO expression, mares can be divided into 2 groups. The majority shows a strong IDO immunoreactivity in glandular epithelia (defined as group 1 mares), whereas glandular epithelia of some mares are mostly immunonegative (defined as group 2 mares). These data suggest that the clinical manifestation "susceptible mare" may be caused by different types of immunological dysfunctions including an overstimulation of TLRs, aberrant immune mechanisms associated with higher degrees of endometrosis or a reduced glandular IDO production. For future comparative studies on susceptible and resistant mares, the endometrial biopsy is a necessary tool, since it allows the direct correlation between histopathological findings and the expression of immunological components.
\end{abstract}

Keywords: endometrium / innate immunity / immunomodulation / mare

Citation: Schöniger S., Gräfe H., Schoon H.-A. (2018) Innate immunity mechanisms of the equine endometrium - benefit or harm? Pferdeheilkunde 34, 5-11; DOI DOI 10.21836/PEM20180101

Correspondence: PD Dr. Sandra Schöniger, Institute of Veterinary Pathology, Faculty of Veterinary Medicine, Leipzig University, Germany; sandra.schoeniger@vetmed.uni-leipzig.de

\section{Introduction}

Endometrial diseases are the most important cause of reduced fertility in mares and can have a major economic impact on the horse breeding industry. These include different forms of endometritis, endometrosis (periglandular fibrosis), angiosclerosis and glandular maldifferentiation during the breeding season (Schoon et al. 1997). Suppurative and non-suppurative endometritis represent the most frequent forms of endometrial inflammation (Schoon et al. 1997), whereas endometritis eosinophilica (Grimm et al. 2017) and histiocytic or granulomatous forms are seldom diagnosed (Ellenberger et al. 2006). With the exception of suppurative endometritis, the other endometrial diseases are usually subclinical and can only be diagnosed by the microscopic examination of an endometrial biopsy (Schoon et al. 1997). This method is also used for prognostication of fertility (Kenney and Doig 1986, Schoon et al. 1997).

Whereas suppurative endometritis is most commonly caused by an ascending bacterial infection, the cause and pathogenesis of non-suppurative endometritis is still undetermined (Schoon et al. 1997). The reason for the increased susceptibility of some mares ("susceptible mares") to develop persistent post-breeding endometritis is also unsolved so far (Troedsson and Woodward 2016). For these two inflammatory conditions, a contribution of immune mediated pathomechanisms is suspected (Schoon et al. 1997, Fedorka et al. 2016, Troedsson and Woodward 2016).
The initial cause and the pathogenesis of endometrosis is also unclear (Buczkowska et al. 2014). Research data suggest that factors of the innate and adaptive immunity may be involved in the development of endometrosis; possibly contributing factors include periglandular accentuated mononuclear inflammatory cell infiltrates (Klose et al. 2016), neutrophilic extracellular traps (Rebordão et al. 2014) and the release of profibrotic cytokines (Rebordão et al. 2014).

The innate immunity provides the immediate defence against pathogens, activates the adaptive immunity and regulates tissue homeostasis (Turvey and Broide 2010). It consists of phagocytic cells (macrophages, neutrophils), Toll-like receptors (TLRs) and nucleotide-binding oligomerisation domain-like receptors (NLRs) that recognize conserved pathogen associated molecular patterns (PAMPs), proinflammatory cytokines as well as antimicrobial peptides (Turvey and Broide 2010). TLRs are associated with cellular membranes and can be activated by different extra- and intracellular infectious agents (Turvey and Broide 2010). Since NLRs are located in the cytoplasm, their main ligands are intracelluar pathogens (Turvey and Broide 2010). The activation of these receptors results in signal transduction pathways that initiate the production of proinflammatory mediators as well as antimicrobial peptides such as lysozyme and defensins (Kannaki et al. 201 1, Philpott et al. 2014). The latter can directly lyse pathogens (Bruhn et al. 2011).

In addition, tissues are equipped with immunomodulatory mechanisms, e.g. the production of indoleamine 2,3-dioxy- 


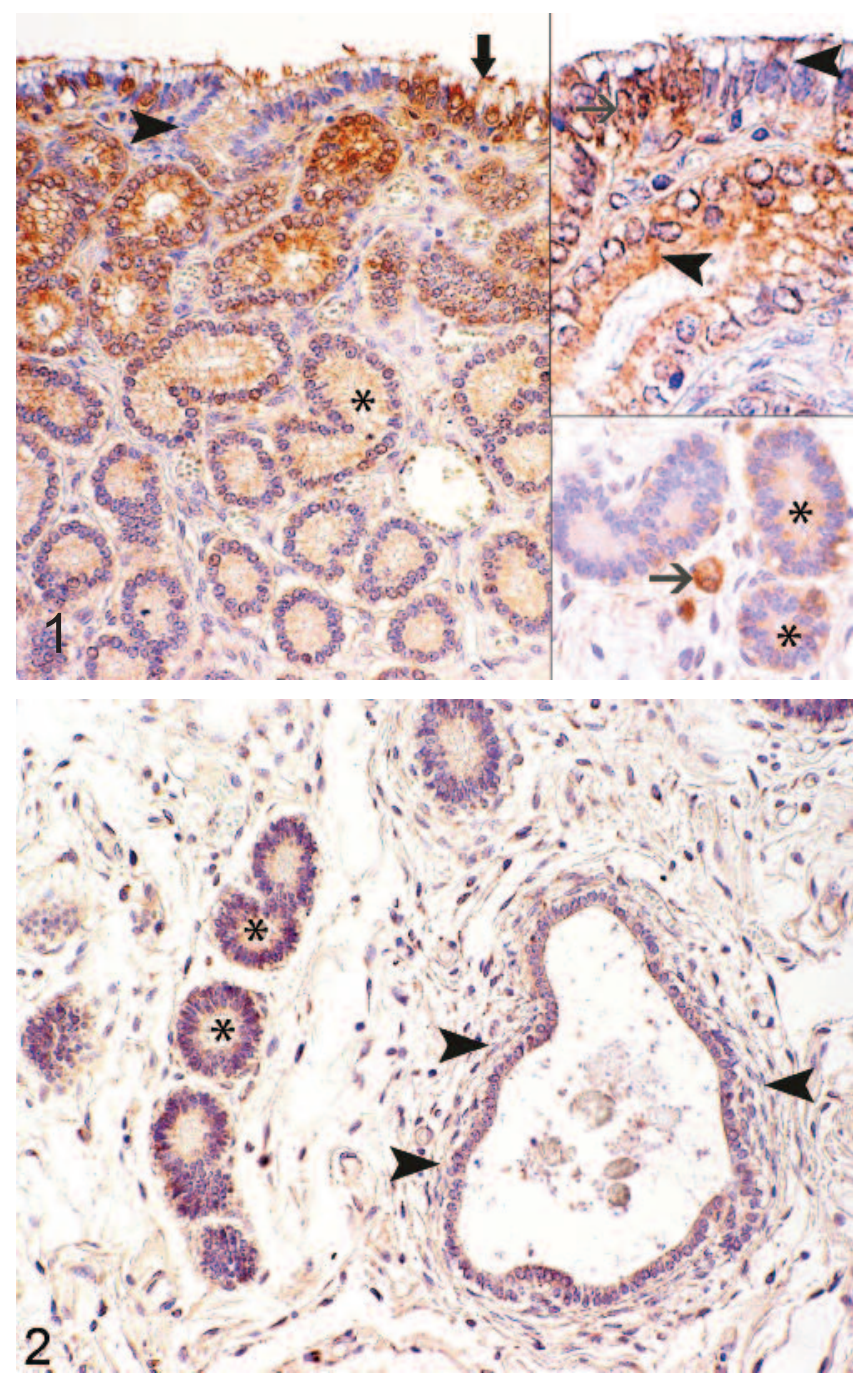

Fig. 1 and 2 - A positive immunostaining for TLRs 2, 4 and 6 is detected mainly in epithelial cells and mast cells. Endometrial tissue samples do not show a uniform epithelial staining pattern; instead marked differences exist between individual mares. Fig. 1: Exemplary depicted is an endometrial tissue sample with TLR 6 immunostaining of all epithelial subpopulations, i.e. those lining the luminal surface (thick arrow), glandular ducts (arrowhead) and mid and basal glands (asterisk). Upper inset: The epithelial immunostaining is most commonly located in the cytoplasm (arrowheads), a solely or concurrent nuclear labelling (thin arrow) is less frequently observed. Lower inset: In addition to glandular epithelial cells (asterisks), mast cells (thin arrow) are immunopositive. Fig. 2: In most cases with endometrosis, healthy (asterisks) and endometrotic glands (arrowheads) show a similar TLR immunostaining, as illustrated in a case with TLR 2 immunolabelling

Abb. 1 und 2 - TLRs 2, 4 und 6 werden überwiegend von Epithelzellen und Mastzellen exprimiert. Ein einheitliches epitheliales Expressionsmuster kann nicht detektiert werden, statt dessen finden sich individuelle Unterschiede zwischen den einzelnen Stuten. Abb. 1: Gezeigt wird ein Endometriumbioptat mit einer Expression von TLR 6 in allen epithelialen Subpopulationen, d.h. im Oberflächenepithel (dicker Pfeil), im Epithel der Drüsenausführungsgänge (Pfeilspitze) und in den mittleren und tiefen Drüsenabschnitten (Sternchen). Oberes Inset: Die Immunreaktion der Epithelzellen befindet sich am häufigsten im Zytoplasma (Pfeilspitze) und seltener ausschließlich oder zusätzlich im Zellkern (dünner Pfeil). Unteres Inset: Zusätzlich zu glandulären Epithelzellen (Sternchen) sind Mastzellen (dünner Pfeil) immunpositiv. Abb. 2: In den meisten Endometrien mit Endometrose zeigen endometrotische (Pfeilspitzen) und gesunde Drüsen (Sternchen) eine vergleichbare Expression der untersuchten TLRs; dies wird am Beispiel von TLR 2 gezeigt. genase (IDO). This tryptophan degrading enzyme is particularly expressed in mucous membranes and immune privileged sites such as testis, placenta and lymphoid organs (Mellor and Munn 2004). It has also been detected in epithelial cells and macrophages of the non-pregnant endometrium of women (Sedlmayr et al. 2002) and mice (Jeddi-Tehrani et al. 2009). Tryptophan is required for bacterial growth and the activation of effector T cells (Mellor and Munn 2004). Its depletion is associated with retardation of bacterial proliferation, inhibition of $T$ cell mediated immune responses and stimulation of regulatory T cells (Mellor and Munn 2004).

\section{Study results on innate immunity mechanisms of the equine endometrium with the spotlight on TLRs, NLRs, beta-defensin and IDO}

It has been shown that the equine endometrium is equipped with various components of the afferent and efferent arms of the innate immunity. Afferent receptors include different TLRs (Cuervo-Arango et al. 2009, Atli et al. 2010a and b, Eaton et al. 2010, Nash et al. 2010, Marth et al. 2015, Siemieniuch et al. 2016, Schöniger et al. 2017a and b) and NLRs (Marth et al. 2015, Schöniger et al. 2017c). Identified effector mechanisms encompass the production of proinflammatory cytokines (Marth et al. 2015, Siemieniuch et al. 2016) as well as antibacterial peptides, e.g. beta-defensin (Schöniger et al. 2013 and 2016, Marth et al. 2015), lactoferrin (Kolm et al. 2006) and lysozyme (Marth et al. 2015). In addition, the immunomodulatory factor IDO is expressed as well.

\section{Toll-like receptors}

In equine endometrial tissue samples, transcripts of TLRs 1 - 10 as well as MD 2, the cofactor of TLR 4, are identified (Cuervo-Arango et al. 2009, Atli et al. 2010a and b, Eaton et al. 2010, Nash et al. 2010, Marth et al. 2015, Siemieniuch et al. 2016, Schöniger et al. 2017a and b). An influence of the stage of the endometrial cycle and an established pregnancy on transcript levels of TLRs 1-10 is described (Atli et al. $2010 a, b)$. Insemination induces changes in TLR 4 transcript levels that are different in resistant and susceptible mares (Cuervo-Arango et al. 2009, Eaton et al. 2010). Gene expression analysis on endometrial biopsies of mares reveals that an experimental intrauterine inoculation with $E$. coli increases the expression of TLRs 2 and 4, MD 2 and CD1 4 as well as associated signal transduction molecules (Marth et al. 2015). Similar effects are observed regardless if the treatment with $\mathrm{E}$ coli is performed during oestrus or dioestrus (Marth et al. 2015). Transcript levels of TLRs 2 and 4 are increased in equine endometrial biopsies with subacute suppurative endometritis in comparison to those with chronic endometritis and biopsies without inflammation (Siemieniuch et al. 2016).

Studies on TLRs 2, 4 and 6 confirm their expression as proteins as well (Siemieniuch et al. 2016, Schöniger et al. 2017a and b). Immunohistochemistry on tissue sections of the healthy and diseased endometrium reveals that TLRs 2, 4 and 6 are present in different cell populations, i.e. mainly in epithelial cells and mast cells (Fig. 1) and less frequently in stromal cells, mononuclear inflammatory cells and vascular endothe- 
lia and smooth muscle cells (Schöniger et al. 2017a). Although TLRs 2 and 4 are more frequently observed in epithelial cells lining the luminal surface and glandular ducts than in epithelia of mid and basal glands, no uniform epithelial expression pattern of TLRs 2, 4 and 6 can be detected (Schöniger et al. 2017b). Instead, individual mares show marked differences regarding the receptor distribution amongst the epithelial subtypes and the numbers of immunopositive cells (Schöniger et al. 2017b). In epithelial cells, the immunosignal is most frequently located in the cytoplasm and seldom in the nucleus or simultaneously in the nucleus and cytoplasm (Schöniger et al. 2017a and b; Fig. 1). The other immunopositive cell populations show solely a cytoplasmic immunolabelling (Schöniger et al. 2017a; Fig. 1). The functional morphology of endometrial glands or the presence of endometrial diseases has no obvious influence on the expression of TLRs 2, 4 and 6 (Siemieniuch et al. 2016, Schöniger et al. $2017 a$ and b). In the examined tissue samples, endometrotic glands commonly show a similar protein expression for TLRs 2, 4 and 6 than the adjacent healthy mid and basal glands (Schöniger et al. 2017b; Fig. 2).

\section{Nucleotide-binding oligomerisation domain-like receptors}

By PCR, transcripts of NOD1 and NOD2 are detected in tissue samples of the healthy and diseased equine endometrium indicative of a constitutive expression (Schöniger et al. 2017c). Gene expression analysis of mares prior and after experimental intrauterine inoculation with $\mathrm{E}$. coli reveals an increased gene expression of certain NLRs including NLRC4, NLRC5, NLRP3, NLRP12 after bacterial inoculation in oestrus and dioestrus (Marth et al. 2015).

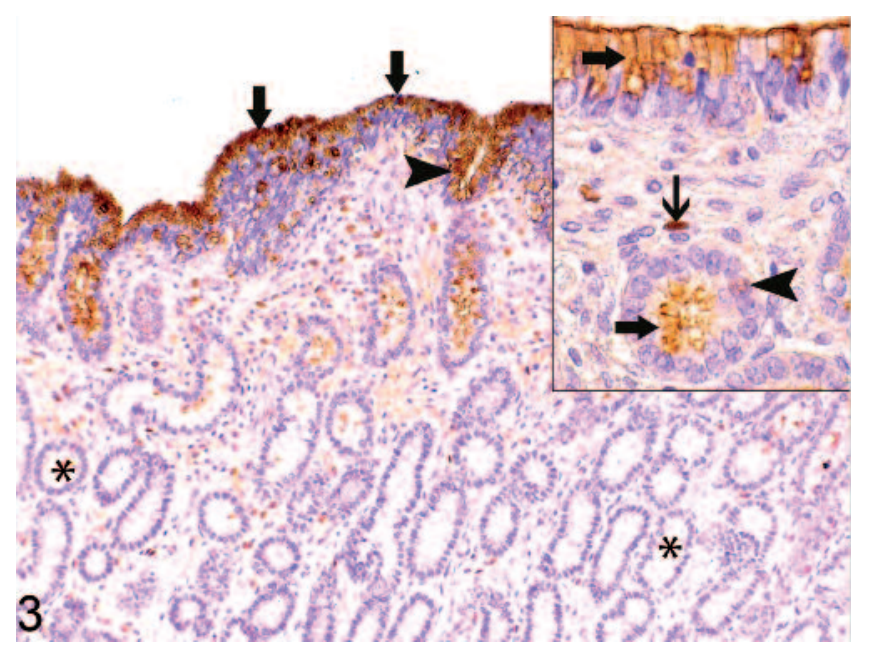

Beta-defensin

Transcripts and proteins of beta-defensin are detected in the healthy and diseased equine endometrium (Schöniger et al. 2013 and 2016). Experimental intrauterine inoculation with E. coli increases the endometrial expression of the betadefensin 1 gene (Marth et al. 2015).

By immunostaining for beta-defensin, all examined tissue samples show a positive labelling of epithelial cells and some contain scattered positive stromal cells and/or vascular smooth muscle cells as well (Schöniger et al. 2013 and 2016; Fig. 3). Numbers of immunopositive cells vary considerably between endometrial tissue samples of different mares (Schöniger et al. 2013 and 2016). In most cases, epithelial cells show a cytoplasmic immunostaining and only in very few cases a solely or concurrent nuclear immunoreaction (Fig. 3). The immunostaining of stromal cells is solely nuclear and the immunoreaction of vascular smooth muscle cells is nearly exclusively located in the cytoplasm (Schöniger et al. 2013 and 2016; Fig. 3). There is a distinct polarization of the beta-defensin immunostaining towards the luminal surface, i.e. the immunosignal is mostly observed in epithelial cells lining the luminal surface and glandular ducts and only rarely in healthy mid and basal glands (Schöniger et al. 2013, 2016; Fig. 3). Endometrotic glands, however, frequently show a positive beta-defensin expression (Schöniger et al. 2016; Fig. 4).

\section{Indoleamine 2,3-dioxygenase}

The healthy and diseased non-pregnant equine endometrium contains IDO transcripts and proteins. This enzyme is detec-

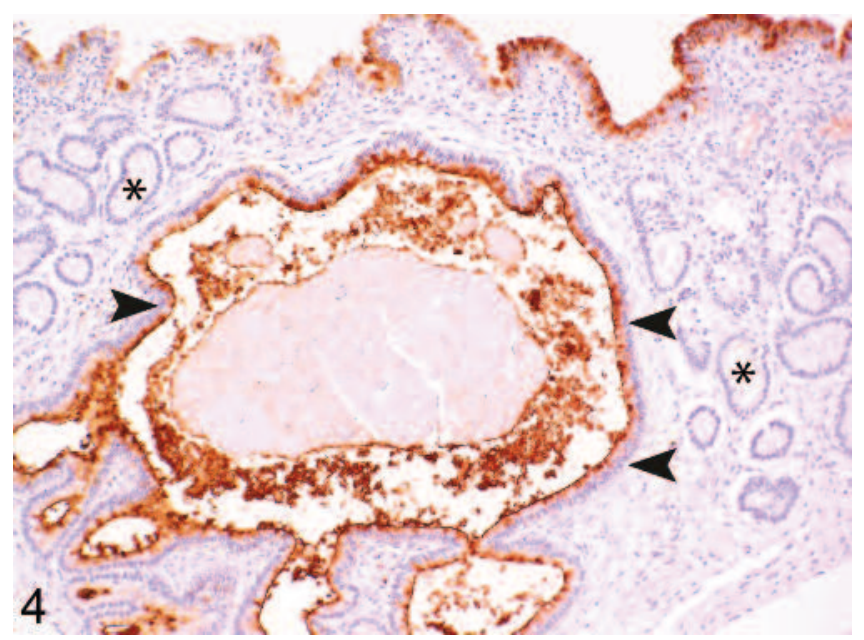

Fig. 3 and 4 - Beta-defensin immunostaining is observed in epithelial cells and in a few cases also in stromal cells. Fig. 3: The epithelial immunolabelling shows a polarization towards the uterine lumen, i.e. the immunosignal is mostly detected in epithelial cells of the luminal surface (thick arrows) and glandular ducts (arrowhead) and rarely in those of healthy mid and basal glands (asterisks). Inset: Superficial epithelial cells have mainly a cytoplasmic immunolabelling (thick arrows), whereas a nuclear immunosignal (arrowhead) is seldom observed. The immunostaining of stromal cells is always nuclear (thin arrow). Fig. 4: In contrast to healthy mid and basal glands (asterisks), endometrotic glands are frequently beta-defensin immunopositive. The arrowheads depict a markedly dilated endometrotic gland.

Abb. 3 und 4 - Eine Expression von beta-Defensin findet sich überwiegend in Epithelzellen und in einigen Fällen auch in wenigen Stromazellen. Abb. 3: Die untersuchten Endometrien zeigen ein charakteristisches lumennahes epitheliales beta-Defensin-Expressionsmuster. Die Immunreaktion liegt überwiegend im Oberflächenepithel (dicke Pfeile) und den Epithelzellen der Drüsenausführungsgänge (Pfeilspitze) vor, während die Epithelien gesunder mittlerer und basaler Drüsenanteile (Sternchen) nur selten immunpositiv sind. Inset: Die lumennahen Epithelzellen (dicke Pfeile) weisen meistens ausschließlich eine zytoplasmatische Immunreaktion auf. Eine alleinige oder gleichzeitige nukleäre Expression von betaDefensin (Pfeilspitze) findet sich selten. In den Stromazellen liegt immer eine nukleäre Reaktion vor (dünner Pfeil). Abb. 4: Im Vergleich zu gesunden Drüsenanteilen (Sternchen), sind endometrotische Drüsen häufig beta-Defensin immunpositiv. Die Pfeilspitzen markieren eine dilatierte endometrotische Drüse. 
ted in the cytoplasm of epithelial cells and mononuclear cells of the stroma consistent with macrophages (Figs. 5 and 6). Based on immunohistochemical findings, two groups of mares can be identified. Most mares (group 1) display a marked expression of IDO in epithelial cells, whereas the immunosignal is mostly located in mid and basal glands (Fig. 5). The remaining mares (group 2) lack an epithelial immunostaining or contain only small numbers of immunopositive epithelial cells (Fig. 6). In group 1 mares with endometrosis, endometrotic glands mostly lack IDO expression (Fig. 5).

\section{Discussion}

Equine endometrial epithelial cells: watchdog and warrior of the innate immunity

The presented data indicate an important role of epithelial cells for the innate immune defences of the equine endometrium and show that these cells do not merely represent a mechanical barrier. Due to their expression of TLRs (Siemieniuch et al. 2016, Schöniger et al. 2017a), they likely function as "watchdog" for PAMPs. Their concurrent production of defensins (Schöniger et al. 2013 and 2016) implicates that the activation of TLRs may directly stimulates the antibacterial fight ("warrior function").

Intrauterine bacterial entry mostly occurs through an ascending infection and during breeding or insemination (Troeds-

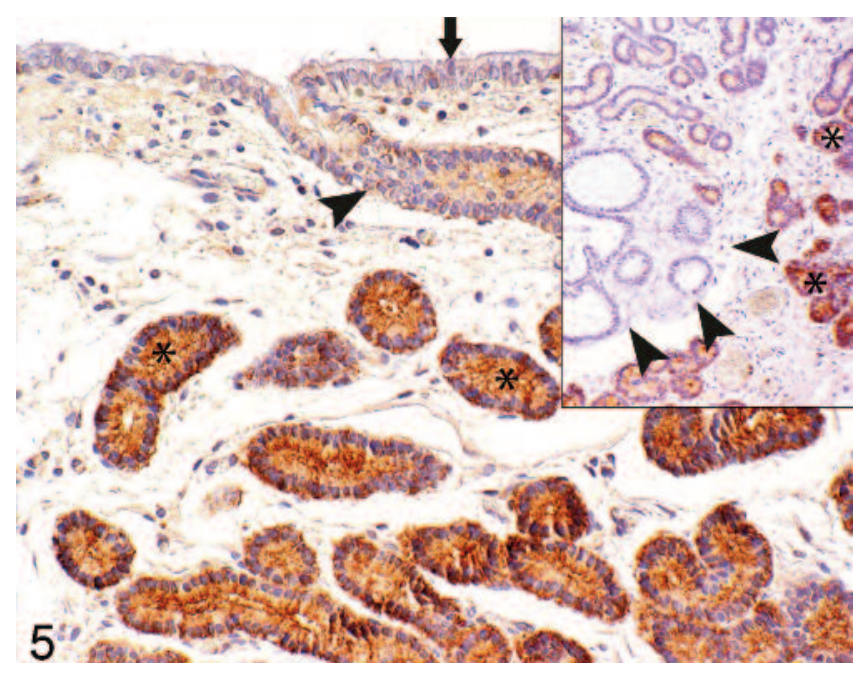

son 2011 ). In this case, the activation of TLRs or NLRs will be beneficial for uterine health, since it helps to clear a bacterial infection and restores tissue homeostasis (Girling and Hedger 2007, Kannaki et al. 2011, Philpott et al. 2014, van Gorp et al. 2014).

Equine endometrial epithelial cells show a polarized expression pattern for beta-defensin and IDO, but not TLRs 2, 4 and 6 (Schöniger et al. 2013, 2016 and 2017a,b,c), whereby the production of beta-defensin and IDO can be induced by TLR stimulation (Palazzo et al. 2007, Kannaki et al. 2011, Wang et al. 2011 1). Notably, the observed expression pattern of betadefensin and IDO is opposite, i.e. the beta-defensin immunoreaction is mainly restricted to the surface and glandular duct epithelium (Schöniger et al. 2013 and 2016), whereas IDO protein is predominantly detected in glandular epithelia. This implicates functional differences between superficial epithelia and epithelia of mid and basal glands. The beta-defensin secretion by superficial epithelia probably directly destroys bacterial pathogens, whereas IDO production in glandular epithelia may restrict bacterial growth. The latter could predispose to bacterial dormancy (Petersen et al. 2015). The markedly diminished production of IDO in glandular epithelia of group 2 mares may alter the physiological immune defense mechanisms of the equine endometrium and could predispose to infection and/or chronic inflammation.

Bacterial infection, breeding or insemination may result in tissue damage and the release of "danger associated molecular

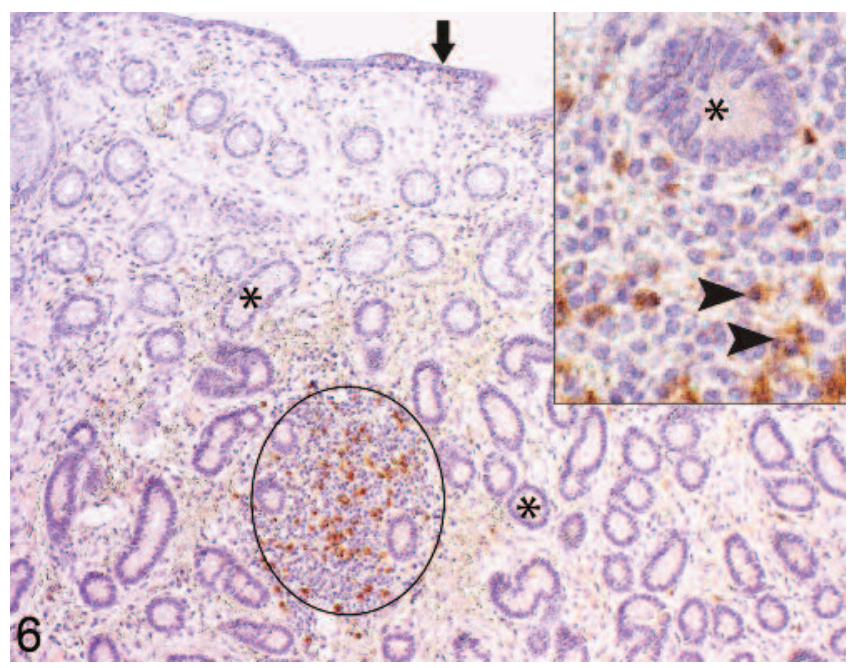

Fig. 5 and 6 - An IDO immunoreaction is observed in epithelial cells and in mononuclear cells of the stroma consistent with macrophages. The immunosignal is always located within the cytoplasm. Fig. 5: In most mares, IDO immunopositive cells are predominantly observed in healthy mid and basal glands (asterisks) and unfrequently in the epithelium lining the luminal surface (thick arrow) and the glandular ducts (arrowhead). Inset: In comparison to healthy glands (asterisks), endometrotic glands (thick arrows) are mostly immunonegative. Fig. 6: In a few mares, epithelial cells of the luminal surface (thick arrow) and glandular ducts as well as healthy and endometrotic mid and basal glands (asterisks) are immunonegative or contain only a few weakly positive cells, whereas the immunostaining of mononuclear cells is preserved. Depicted is a focal periglandular infiltration with lymphocytes and IDO immunopositive macrophages (circle). Inset: An IDO immunonegative gland (asterisk) and IDO positive macrophages (arrowheads) are shown in higher magnification.

Abb. 5 und 6 - Eine Expression von IDO findet sich in Epithelzellen und im Stroma gelegenen mononukleären Zellen passend zu Makrophagen. Beide Zellpopulationen haben eine zytoplasmatische Immunreaktion. Abb. 5: Endometriumbioptate der meisten Stuten zeigen eine polarisierte Expression von IDO, d.h. die Immunreaktion liegt überwiegend in den mittleren und tiefen Abschnitten gesunder Drüsen (Sternchen) vor, während das Oberflächenepithel (dicker Pfeil) und die Drüsenausführungsgänge (Pfeilspitze) nur selten einige schwach positive Zellen enthalten. Inset: Im Gegensatz zu der starken Immunreaktvität gesunder Drüsen (Sternchen), sind endometrotische Drüsen immunnegativ oder nur geringgradig positiv (Pfeilspitzen). Abb. 6: In wenigen Endometriumbioptaten findet sich eine fehlende oder nur sehr schwache Immunreaktivität nicht nur des Oberflächenepithels (dicker Pfeil) und des Epithels der Drüsenausführungsgänge, sondern auch der mittleren und tiefen gesunden und endometrotischen Drüsenanteile (Sternchen). Die Immunreaktivität der Makrophagen ist jedoch erhalten. Das Oval markiert eine fokale periglanduläre Infiltration mit Lymphozyten und IDO-immunpositiven Makrophagen. Inset: In höherer Vergrößerung gezeigt sind eine IDO-immunnegative Drüse (Sternchen) sowie mehrere IDO-exprimierende Makrophagen (Pfeilspitzen). 
patterns" (DAMPs). The additional activation of TLRs or NLRs by DAMPs could evoke a vicious cycle of inflammation and antimicrobial defences with secondary tissue damage and fibrosis and the further stimulation of these receptors (Lafyatis and Farina 2012, Tang et al. 2012).

The observed nuclear immunostaining for beta-defensin (Schöniger et al. 2013 and 2016) and TLRs 2, 4 and 6 (Schöniger et al. $2017 \mathrm{~b}$ ) suggests their possible influence on gene transcription.

\section{Endometrotic glands: localized areas of an aberrant immune} defence

In comparison to healthy glands, endometrotic glands show an altered expression of beta-defensin (Schöniger et al. 2016) and IDO. This suggests the presence of an aberrant immune defence in the endometrium of mares with endometrosis. It appears plausible that the amount of immune deviation increases with the presence of higher degrees of this disease. So far, it is uncertain if the altered expression of beta-defensin and IDO in endometrotic glands represents a sequel to this disease or an early pathogenetic event. The stimulation of TLRs and NLRs as well as high beta-defensin levels may promote proliferation of stromal cells and fibrosis (Wang et al. 2011, Lafyatis and Farina 2012). IDO depletion and the associated higher availability of tryptophan could stimulate $T$ cell associated immune responses (Mellor and Munn 2004). There is evidence for a $\mathrm{T}$ cell driven pathogenesis of non-suppurative endometritis, since the inflammatory cells of non-suppurative endometritis mainly represent CD4 + and/or CD8 + T lymphocytes (Rudolph et al. 2017). Based on these findings, it cannot be ruled out, that higher degrees of endometrosis predispose to the development of non-suppurative endometritis.

The susceptible mare: a clinical manifestation of different types of immunological dysfunctions?

Under consideration of the presented research data, it appears likely that immunological alterations cause or at least contribute to the increased susceptibility of a mare to develop persistent endometritis. Due to the involvement of TLRs, NLRs, defensins and/or IDO in antimicrobial defenses and immune mediated diseases (Mellor and Munn 2004, Prendergast et al. 2011, Gersemann et al. 2012, Philpott et al. 2014), it appears plausible that the clinical manifestation "susceptible mare" could be caused by different types of immunological dysfunctions.

In human beings, it is known that genetic polymorphisms or mutations of TLRs, NLRs or defensins may be associated with either an increased susceptibility or a higher resistance towards infectious or inflammatory diseases (Hollox et al. 2008, Medvedev 2013, Philpott et al. 2014, Ran et al. 2016). The phenotypic manifestations, however, are commonly also influenced by environmental factors (Hollox et al. 2008, Medvedev 2013). Study results on the equine endometrium reveal marked individual differences in the protein expression levels of beta-defensins and TLRs (Schöniger et al. 2013, 2016 and 2017a,b) as well as IDO that may be genetically determined and/or acquired.
Based on the own investigations, it appears possible that the reduced IDO production in group 2 mares as well as the aberrant IDO and defensin expression in endometrotic glands may contribute to an increased susceptibility of a mare towards persisting endometritis. Regarding the latter, it has been shown that endometrial biopsies of susceptible mares are mainly category IIb or III (categorization of Kenney und Doig 1986), whereas those of resistant mares are mostly classified as category I or lla (Christoffersen et al. 2012).

\section{Future implications}

The presented data indicate the presence of a complex and likely interconnected regulation of immunity factors in the equine endometrium. They further implicate that the susceptibility or resistance of a mare towards persistent endometritis may possibly represent the clinical manifestation of different immunological phenotypes. In a next step, it will be important to better characterize the immunological alterations of TLRs, NLRs, beta-defensin and IDO that could possibly result in the clinical manifestation "susceptible mare". For this, the endometrial biopsy is an important diagnostic tool, since it allows to directly correlate pathomorphological endometrial findings with the protein expression pattern of these factors. Results of these studies will improve the genital health of individual mares and will reduce financial losses for the horse breeding industry.

\section{References}

Atli M. O., Kurar E., Kayis S. A., Aslan S., Semacan A., Celik S., Guzeloglu A. (2010a) Expression of Toll-like receptors (TLRs) in the equine endometrium during the estrous cycle. Reprod. Dom. Anim. 45, 58

Atli M. O., Kurar E., Kayis S. A., Aslan S., Semacan A., Celik S., Guzeloglu A. (2010b) Expression of Toll-like receptors (TLRs) is regulated by early pregnancy in the mare endometrium. Biol. Reprod. 83, 349

Bruhn O., Grötzinger J., Cascorbi I., Jung S. (2011) Antimicrobial peptides and proteins of the horse - insights into a well-armed organism. Vet. Res. 42, 98; DOI 10.1186/1297-9716-42-98

Buczkowska J., Kozdrowski R., Nowak M., Ra A., Mrowiec J. (2014) Endometrosis-significance for horse reproduction, pathogenesis, diagnosis, and proposed therapeutic methods. Pol. J. Vet. Sci. 17, 547-554

Christoffersen M., Woodward E., Bojesen A. M., Jacobsen S., Petersen M. R., Troedsson M. H. T., Lehn-Jensen H. (2012) Inflammatory responses to induced infectious endometritis in mares resistant or susceptible to persistent endometritis. BMC Vet Res. 8, 41 ; DOI 10.1186/1746-6148-8-41

Cuervo-Arango J., Worgan H., Macías B., Nash D. (2008) Endometrial toll-like receptor 4 (TLR4) and interleukin 8 (IL-8) expression in mares resistant (RM) or susceptible (SM) to endometritis. Reprod. Dom. Anim. 43, 75

Eaton S., Raz T., Card C. (2010) Toll-like receptor-2 and -4 in the equine endometrium during physiological post-breeding endometritis. Anim. Reprod. Sci. 121S, S96-S97; DOI 10.1016/j.anireprosci.2010.04.067

Ellenberger C., Schoon D., Schoon H.-A. (2006) Außergewöhnliche Befunde bei der Untersuchung von Uterusbiopsien der Stute. Pferdeheilkunde 22, 171-176

Fedorka C. E., Scoggin K. E., Woordward E. M., Squires E. L., Ball B. A., Troedsson M. (2017) The effect of select seminal plasma proteins on endometrial mRNA cytokine expression in mares susceptible to persistent mating-induced endometritis. Reprod. Dom. Anim. 52, 89-96; DOI 10.1111/rda.12813 
Gersemann M., Wehkamp J., Stange E. F. (2012) Innate immune dysfunction in inflammatory bowel disease. J Int. Med. 271, 421428; DOI 10.1111/i.1365-2796.2012.02515

Girling J. E., Hedger M. P. (2007) Toll-like receptors in the gonads and reproductive tract: emerging roles in reproductive physiology and pathology. Immunol. Cell. Biol. 85, 481-489; DOI 10.1038/sj.icb.7100086

Grimm A. L., Schoon H.-A., Schöniger S. (2017) Histopathological features of endometritis eosinophilica in mares. Histol. Histopathol. 32,1161-1173; DOI 10.14670/HH-11-872.

Hollox E. J., Barber J. C., Brookes A. J. Armour J. A. (2008) Defensins and the dynamic genome: what we can learn from structural variation at human chromosome band 8p23.1. Genome Res.18, 1686-1697; DOI 10.1101/gr.080945.108

Jeddi-Tehrani M., Abbasi N., Dokouhaki P., Ghasemi J., Rezania S., Ostadkarampour M., Rabbani H., Akhondi M. A., Tahmasebi Fard Z., Zarnani A. H. (2009) Indoleamine 2,3-dioxygenase is expressed in the endometrium of cycling mice throughout the oestrous cycle. J. Reprod. Immunol. 80, 41-48; DOI 10.1016/i.jri.2009. 02.003

Kannaki T. R., Shanmugam M., Verma P. C. (2011) Toll-like receptors and their role in animal reproduction. Anim. Reprod. Sci. 125, 112; DOI 10.1016/i.anireprosci.2011.03.008

Kenney R. M., Doig P. A. (1986) Equine endometrial biopsy. In: Morrow D.A. (Ed.), Current therapy in theriogenology, 2nd Ed., WB Saunders, Philadelphia, USA, pp. 723-729

Klose K., Schoon H.-A. (2016) Periglandular inflammatory cells in the endometrium of the mare - a physiological defence mechanism which impacts on the development of endometrosis? Pferdeheilkunde 32, 15-23

Kolm G., Klein D., Knapp E., Watanabe K., Walter I. (2006) Lactoferrin expression in the horse endometrium: relevance in persisting mating-induced endometritis. Vet. Immunol. 114, 159-167; DOI 10.1016/i.vetimm.2006.08.005

Lafyatis R., Farina A. (2012) New insights into the mechanisms of innate immune receptor signalling in fibrosis. Open Rheumatol J. 6, 72-79; DOI 10.2174/1874312901206010072

Marth C. D., Young N. D., Glenton L. Y., Noden D. M., Browning G. F., Krekeler N. (2015) Deep sequencing of the uterine immune response to bacteria during the equine oestrus cycle. BMC Genomics 16, 934; DOI 10.1186/s12864-015-2139-3

Medvedev A. E. (2013) Toll-like receptor polymorphisms, inflammatory and infectious disease, allergies and cancer. J. Interferon Cytokine Res. 33, 476-484; DOI10.1089/jir.2012.0140

Mellor A. L., Munn D. H. (2004) IDO expression by dendritic cells: tolerance and tryptophan catabolism. Nature Immunol. 4, 762774; DOI 10.1038/nri1457

Nash D. M., Sheldon I. M., Herath S., Lane E. A. (2010) Markers of the uterine innate immune response of the mare. Anim. Reprod. Sci. 1 19, 31-39; DOI 10.1016/i.anireprosci.2009.11.008

Palazzo M., Balsari A., Rossini A., Selleri S., Calcaterra C., Gariboldi S., Zanobbio L., Arnaboldi F., Shirai Y. F., Serrao G., Rumio C. (2013) Activation of enteroendocrine cells via TLRs induces hormone, chemokine and defensin secretion. J. Immunol. 178, 4296-4303

Petersen M. R., Skive B., Christoffersen M., Lu K., Nielsen J. M., Troedsson M. H., Bojesen A. M. (2015) Activation of persistent Streptococcus equi subspecies zooepidemicus in mares with subclinical endometritis. Vet. Microbiol. 179, 119-125; DOI 10.1016/i.vetmic.2015.06.006

Philpott D. J., Sorbara M. T., Robertson S. J., Croitoru K., Girardin S. E. (2014) NOD proteins: regulators of inflammation in health and disease. Nature Rev. Immunol.14, 9-23; DOI 10.1038/nri3565

Prendergast G. C., Chang M. Y., Mandik-Nayak L., Metz R., Muller A. J. (2011) Indoleamine 2,3-dioxygenase as a modifier of pathogenetic inflammation in cancer and other inflammation-associa- ted diseases. Curr. Med. Chem. 18, 2257-2262; DOI 0929$8673 / 11$

Ran X., Chen J., Chen L., Li Y., Wu M. (2016) Beta-defensin gene (DEFB1) polymorphisms are associated with the susceptibility to chronic respiratory diseases. Genes Genom. 38, 645-658; DOI 10.1007/s13258-016-0388-4

Rebordão M. R., Galvão A., Szóstek A., Amaral A., Mateus L., Skarzynski D. J., Ferreira-Dias G. (2014) Pathophysiological mechanisms involved in mare endometrosis. Reprod. Dom. Anim 49. (Suppl. 4) 82-87; DOI 10.1111/rda.12397

Rudolph N., Schoon H.-A., Schöniger S. (2018) Immunohistochemical characterisation of immune cells in fixed equine endometrial tissue: a diagnostic relevant method. Pferdeheilkunde 34, 524 537; DOI 10.21836/PEM20170601

Schöniger S., Böttcher D., Theuß T., Gräfe H., Schoon H.-A. (2017a) Expression of Toll-like receptors 2, 4 and 6 in different cell populations of the equine endometrium Vet Immunol Immunopathol. 185, 7-13; DOI 10.1016/i.vetimm.2017.01.002

Schöniger S., Böttcher D., Theuß T., Schoon H.-A. (2017b) Expression of Toll-like receptors 2, 4 and 6 in equine endometrial epithelial cells: A comparative in situ and in vitro study. Res Vet. Sci. 112, 34-41; DOI 10.1016/i.rvsc.2017.01.004

Schöniger S., Gräfe H., Richter F., Helmschrodt C., Schoon H.-A. $(2017$ c) Expression of NOD1 and NOD2 transcripts in the healthy and diseased equine endometrium. Pferdeheilkunde 33, 216222; DOI 10.21836/PEM20170301

Schöniger S., Böttcher D., Theuß T., Gräfe H., Schoon H.-A. (2016) New insights into the innate immune defences of the equine endometrium: in situ and in vitro expression pattern of beta-defensin. Pferdeheilkunde 32, 4-14; DOI 10.21836/PEM20160101

Schöniger S., Gräfe H., Schoon H.-A. (2013) Beta-defensin is a component of the endometrial immune defence in the mare. Pferdeheilkunde 29, 335-346; DOI 10.21836/PEM20130307

Schoon H.-A., Schoon D., Klug E. (1997) Die Endometriumbiopsie bei der Stute im klinisch-gynäkologischen Kontext. Pferdeheilkunde 13, 453-464; DOI 10.21836/PEM19970506

Sedlmayr P., Blaschitz A., Wintersteiger R., Semlitsch M., Hammer A., MacKenzie C. R., Walcher W., Reich O., Takikawa O., Dohr G. (2002) Localization of indoleamine 2,3-dioxygenase in human reproductive organs and the placenta. Mol. Human Reprod. 8, 385-391

Siemieniuch M. J., Szóstek A. Z., Gajos K., Kozdrowski R., Nowak M., Okuda K. (2016) Type of inflammation differentially affects expression of interleukin 1 and 6, tumor Necrosis Factor- and Toll-like receptors in subclinical endometritis in mares. PLoS One 11 (5), e0154934; DOI 10.1371/journal.pone.0154934

Tang D., Kang R., Coyne C., Zeh H. J., Lotze M. T. (2012) PAMPs and DAMPs: Signal Os that spur autophagy and immunity. Immunol. Rev. 249, 158-175; DOI 10.1111/j.1600-065X.2012. $01146 . x$

Troedsson M. H. T., Woodward E. M. (2016) Our current understanding of the pathophysiology of equine endometritis with an emphasis on breeding-induced endometritis. Reprod. Biol. 16, 812; DOI 10.1016/i.repbio.2016.01.003

Troedsson M. H. T. (2011). Endometritis. In: Equine Reproduction. 2nd Ed., Volume 2, McKinnon A. O., Squires E. L., Vaala W. E., Varner D. D. Wiley-Blackwell, pp. 2608-2619

Turvey S. E., Broide D. H. (2010) Innate immunity. J. Allergy Clin. Immunol. 125, S24-32; DOI 10.1016/j.jaci.2009.07.016

van Gorp H., Kuchmiy A., Van Hauwermeiren F., Lamkanfi M. (2014) NOD-like receptors interfacing the immune and reproductive systems. FEBS J. 281, 4568-4582; DOI 10.1111/febs.13014

Wang B., Koga K., Osuga Y., Cardenas I., Izumi G., Takamura M., Hirata T., Yoshino O., Hirota Y., Harada M., Mor G., Taketani Y. (2011) Toll-like receptor-3 ligation-induced indoleamine 2,3-dioxygenase expression in human trophoblasts. Endocrinology 152, 4984-4992; DOI 10.1210/en.2011-0278 